\title{
CONTROLLING IN SMES-IMPLEMENTATION AND IMPLEMENTATION OBSTACLES IN GERMANY, FRANCE AND TURKEY
}

\author{
KOBİLERDE YÖNETIMM MUHASEBESI-ALMANYA, FRANSA VE \\ TÜRKIYY'DE UYGULAMA VE UYGULAMA ENGELLERİ
}

\section{Çağla ERSEN CÖMERT* Viktor MENDEL ${ }^{* *}$ Stephan SCHONING ${ }^{* *}$}

\begin{abstract}
Controlling is increasingly important in a changing economic environment. Nevertheless, many SMEs in Germany, France and Turkey have not implemented adequate controlling measures. Besides financial limitations, one main reason seems to be the lack of awareness of the part of managers and the owners of SMEs. Typically, they build up the company and due to their recent success, they believe they can only make a few mistakes and need any foundation of decisions using controlling measures. An additional aspect to be investigated is the influence of national culture. In this paper, the authors present the background and basic considerations for the design of an empirical investigation analyzing the evidence for the influence of culture on controlling systems. The ongoing research project will try to provide empirical proof of the influence of cultural differences on the design and implementation of controlling systems.
\end{abstract}

Keywords: Controlling, SME, intercultural factors

JEL Classification: M1, M410

Öz

Değişen bir ekonomik ortamda kontrol giderek daha önemlidir. Bununla birlikte, Almanya, Fransa ve Türkiye'deki birçok KOBİ yeterli kontrol önlemleri uygulamamıştır. Finansal sınırlamaların yanı sıra,

* Assoc. Prof. Dr., Marmara University, Faculty of Business Administration, caglaersen@marmara.edu.tr, ORCID: 0000-0002-7147-1665.

** M.A., WMF Group Geislingen/Steige, viktor.mendel@wmf.de, ORCID: 0000-0002-0078-1949.

*** Prof. Dr. habil., SRH University of Applied Sciences Heidelberg Campus Calw, stephan.schoening@srh.de, ORCID: 0000-0003-1343-9445.

Tocite this article: Ersen Cömert, Ç., Mendel, V. \& Schöning S. (2019). Controlling in SMEs - Implementation and Implementation Obstacles in Germany, France and Turkey. Journal of Research in Business, 4(1), 64-81. DOI: 10.23892/JRB.2019453296 
ana nedenlerden biri yöneticilerin ve KOBİ sahiplerinin bir kısmının farkında olmama gibi görünüyor. Genellikle, şirketi kurarlar ve son başarılarından dolayı, sadece birkaç hata yapabileceklerine ve kontrol tedbirlerini kullanarak herhangi bir karar vakfına ihtiyaç duyabileceklerine inanırlar. Araştırılacak ek bir husus, ulusal kültürün etkisidir. Bu yazıda yazarlar, kültürün kontrol sistemleri üzerindeki etkisine ilişkin kanıtları analiz eden ampirik bir araştırmanın tasarımı için temel ve temel düşünceleri sunmaktadır. Devam eden araştırma projesi, kültürel farklılıkların kontrol sistemlerinin tasarımı ve uygulanması üzerindeki etkisine dair ampirik kanıt sağlamaya çalışacaktır.

Anahtar Kelimeler: Kontrol, KOBİ, kültürlerarası faktörler

JEL Classification: M1, M410

\section{Introduction}

\subsection{Background}

Small and medium enterprises (SMEs) in both in Turkey, France and Germany are particularly important for the national economy. This is especially true for the provision of jobs and training places and the innovative power (Alptürk 2008, Müftüoğlu 2002, 51ff, Haşit 2009, Rehn 1998, 36f.).

Due to their especially lower internal bureaucracy, SMEs are commonly regarded to be more innovative than large enterprises. However, this is not reflected, for example in Germany, by patent applications or product / process innovations (Maaß \& Führmann 2012). When organizational innovations are additionally considered, this image changes: $78 \%$ of companies with 10 to 49 and $84 \%$ of companies with 50 to 249 employees participate in the innovation process, compared to large corporates with 95\%. Therefore, SMEs are more innovative than previously reported (Rammer et al. 2014). One always has to keep in mind, that a stable innovation process is a "condition sine qua non" in the global competition.

In both countries, SMEs are faced with growing challenges:

The transformation of the society leads to an increasing pressure of various stakeholders (Christopher \& Towill 2002, 3). Examples are environmental protection, ethics, "of mature" consumers etc.

The economic world in general is newly-minted by New Economy and internet-based concepts and solutions gene (Emre \& Budak 2006).

The competition increases in the wake of internationalization and globalization. This is accompanied by:

a complex and dynamic competitive environment (Chapman \& Ward 2003 1053; Giddens 2003; Miller 1998, 500; Rahman \& Kumaraswamy 2002, 49f.).

the globalization of markets,

shorter product life cycles, and

complex linkages within corporate networks. 
Uncertainties of supply and demand often bring companies in risky situations (Craighead, Blackhurst, Rungtusanatham \& Handfield 2007, 132; Harland, Brenchley \& Walker 2003, 53; Hult, Ketchen \& Slater 2004, 244): Even events in distant regions can influence persons and organizations who are otherwise completely uninvolved (Beck 1992, 29).

In this increasingly complicated environment, it should not be forgotten that, for companies, there is no alternative to risk taking. Addressing the challenges involves and requires taking entrepreneurial risk. In this environment, controlling becomes essential for company to avoid negative developments and to detect opportunities within an increasingly internationalized environment (Mäder \& Hirsch 2009).

\subsection{Content and Approach of the Overall Project}

Within the environment outlined above, the research project consists of gathering insights into controlling in German, French and Turkish SMEs. The projects aims at increasing the penetration of controlling skills and in so doing, improving the resistance against risks of this economically very important group of companies. The approach of the project can be described by the following three steps:

Analysis of the current state-of-the-art of controlling in SMEs in the countries through literature analysis and derivation of challenges.

Usage of the findings of the literature review for the generation of issues as part of an empirical study with a focus on the socio-cultural aspects of controlling.

Derivation of options for action from the results of empirical study of German, French and Turkish SMEs.

As part of the project, in this article we reflect the following central questions:

How do conceptual factors influence the design of controlling

What are the differences between large companies and SMEs in relation to the design of controlling?

In what ways are there socio-cultural differences in terms of controlling in Germany, France and Turkey?

\section{Controlling and Contextual Factors of Controlling}

\subsection{Definition of Controlling and Controlling Concepts}

Within literature, several definitions and tasks of controlling can be found and the three following definitions are only a brief overview over these different approaches: Horvath (1978) defines controlling as a management system that coordinates planning, control and information supply. 
Peemüller (1992) points out, that controlling is a system whose purpose is to provide management with the information necessary to plan, manage and control the business. Lachnit (1992) assigns controlling to a business service function aimed at assisting management in the goal-oriented management of a business on a conceptual, instrumental and informational basis. Already the definitions show that the role and understanding of controlling differ.

Corresponding to this, several controlling concepts were developed in the course of the evolution of controlling:

Historical-accounting-oriented controlling: Controlling is a management system that provides information about the actual status of the company and updates planning calculations. This controlling concept is recording and documenting. The emphasis is on summarization, overview and information in the sense of reporting.

Future - and action-oriented controlling: The focus of controlling activities is now on examining operational processes, uncovering weak points, introducing and supporting planning and control systems, carrying out target/actual comparisons and variance analyses.

Management system-oriented controlling (Lachnit/Müller 2012): The controller becomes a design carrier and innovator by designing concepts for more effective corporate management. This requires comprehensive knowledge of business techniques such as forecasting, planning, control, corporate and environmental analysis or information processing, as well as organization and management systems.

Controlling to secure rationality: According to Weber $(2002,48)$, the role of controlling is understood as securing the rationality of management or ensuring the effectiveness and efficiency of management. The task of controlling aims at supporting the assurance of rational corporate management.

In sum, controlling, in different amount, is leadership supportive, system-forming and systemconnecting.

\subsection{Context Factors of Controlling}

Which of the concepts is used in a company depends, among other things, on internal and external aspects (context factors). Thus, many empirical analyses show a strong context dependence of the level of development of controlling (Kosmider 1994; Niedermayr 1997; Ossadnik, Barklage \& Lengerich 2004; Zimmerman 2001; Dintner 1999).

Internal company context factors: company size, organizational structure, industry affiliation, information technologies used.

External context factors in controlling: Corporate environment such as (general) information technologies, legal rules, competitor, industrial sector and culture. 
It is obvious that the stability (or speed of change) of the corporate environment determines the role and task of the controller:

In a relatively static environment, the controller acts as an accounting-oriented "registrar".

In a limited dynamic environment, the controller performs the tasks of a "navigator" by providing planning and control assistance.

In an extremely dynamic environment, the controller is an innovator involved in problem-solving processes (Zünd 1979)

In sum, many features characterizing a company such as structure, company size, industry, etc., affect the design and implementation of controlling. One must also keep in mind that each national culture is an important determinant of the design of organizational and controlling systems and their effectiveness (Hoffjan \& Boucoiran 2008, 66). Cultural, social, legal and political sub-differences affect the strategic and operative business and thus controlling too.

\subsection{Special Context Factors of Controlling in SMEs}

As mentioned above, small and medium enterprises (SMEs) in Turkey, France and Germany are of particular importance to the national economy for providing employment or ongoing innovation. In all three countries, SMEs have to respond to the growing challenges they are facing due to the increasing competition because of internationalization and globalization, the transformation process especially in the Turkish society or by the New Economy, internet-based concepts and business world solutions newly embossed. SMEs have size-specific advantages and disadvantages in comparison to large enterprises, which are also relevant for the design of controlling. In general, SMEs differ from larger enterprises in limited financial and human resources, individual service provision, simpler organizational and management structures and a stronger entrepreneurial character (Wolf, Kuttner \& Feldbauer-Durstmüller 2017). The following size-specific peculiarities of SMEs have a high influence on the design of controlling (Flacke 2006): Rapid adaptation to environmental changes, reaction pressure, niche market strategies. On the on hand, the smaller size of SMEs can be of specific advantage because they usually have flat hierarchies which enables a more flexible decision making process. On the other hand, SMEs often face

taxation discrimination (Sarisoy \& Sarısoy 2008),

disadvantages of scale as in the field of securing the financial resources,

difficulties with export activities (Kılıç 2011), and

problems enabling corporate governance.

The main barrier for SMEs consists of lack of financial resources, which are required for investments in new technologies (Rautenstrauch \& Müller 2005). 
In general, the lack of investment affects the adaptability of SMEs to the new business world. The lack of financial resources also influences the extent of implementation of controlling systems, which enable founded decision preparatory (Kummert 2005, 155ff.) Consequently, many SMEs in Turkey as well as in Germany and France are far from complete controlling systems.

Apart from financials aspects, the dissemination of controlling instruments in SMEs has been hampered, because these were originally geared to the needs and resources of large companies and therefore not suitable for applications in SMEs (Dintner 1999, Dethlefs 1997, 40ff., Benz, Buchner \& Burgath 1999). However, controlling instruments have meanwhile been developed for the specific needs of SMEs and they are ready for use in companies (Funk, Rossmanith \& Eha 2009, Gleich, Hofmann \& Schulze 2006; Hegglin \& Kaufmann 2003; Müller 2009; Schade 2007; Schulze 2010, also Kramer \& Valentin 2009, 89ff. for an overview). Nevertheless, preliminary studies show that the extent of the practical use of these controlling methods in German, French and Turkish SMEs still is full of gaps. This is unfavorable, both from an individual (company-orientated) and from an overall economic perspective, since potential and existence-threatening risks remain undetected. The question is why do SMEs do not use controlling instruments?

One possible explanation is the SME-specific leadership models which includes both opportunities and risks (Schöning \& Ersen Cörmert 2018):

In SMEs decisions are often made by the company owner/owners "from the gut" i.e. without adequate situational foundations (Rehn 1998, 116ff; Dahms \& Siemes 2005, 230). This aspect is also connected with the concentration and centering of the entire corporate management on the owner(s), who oftentimes is/are closely linked to the corporate formation and evolution. Thus, successful entrepreneurs will often have founded companies or expanded them without adapting their management structures to the growing company size. Such patriarchal or autocratic leadership cultures are distinctive feature of many SMEs.

In general, such a leadership culture can be favorable for the implementation of visionary ideas. Therefore, these leadership structures have led to a brilliant rise of companies in Turkey as well as in Germany. Striking examples for Turkey are Koç or Sabanc1, and for Germany SAP or AWD. However, SME-specific management models also bear risks. Management structures which are oriented on one or a few people are prone to rapid collapse due to seriously wrong entrepreneurial decisions (Rautenstrauch \& Müller 2005). The history of companies is filled with spectacular examples such as Schlecker or Grundig. The analysis of company failures indicates that in addition to companyexternal events (such as a drop of substantial customers or suppliers) primarily corporate causes are responsible for failures. Mitroff \& Alpaslan $(2003,111)$ and Coleman $(2006,5)$ show that exceptional problems that interfere with the organizational routine and based on human errors are more common than in the past. Especially general management shortcomings and wrong decisions as a consequence of serious false assessments in areas like strategic planning, production planning, supply planning, sales planning, human resources planning or financial planning (Hoogen \& Lingnau 2009, Elsweier \& Nickel 2010). These are typical causes of corporate imbalances. 
Especially in owner-managed companies, emerging crisis symptoms are often detected too late or not at all (Rehn 1998, 121f.). An important reason for the emergence of risks and the delayed introduction of countermeasures must be seen in an insufficient foundation of business decisions. As stated before, this is connected with the fact that in SMEs, controlling instruments designed to support decisions are oftentimes only partly implemented (Hoogen \& Lingnau 2009, 112ff, FeldbauerDurstmüller, Duller, Mayr, Neubauer \& Ulrich 2012, Berens, Püthe \& Siemes 2007). In companies that have experienced rapid growth, the foundation of decisions especially reflects the situation in small enterprises. Thus, the need for a controlling process is only seen in part and additionally, the results of the existing instruments are ignored.

Besides financial constraints, the fact that crises do not fit into the self-image of the entrepreneur is in many cases responsible for this. Entrepreneurs tend to ignore that human beings make mistakes, especially because previous economic success seems to be the proof and guarantee that severe mistakes will not occur in the future. Against this background, it is purposeful to analyze why people (and hence also entrepreneurs) error (see Schöning \& Ersen-Cörmert 2018) and whether there is a connection between the establishment of controlling and intercultural differences.

Over all, the qualitative characteristics of SMEs have a significant influence on the design of controlling (Rautenstrauch \& Müller 2005, Wolf, Kuttner \& Feldbauer-Durstmüller 2017).

\section{Socio-Cultural Peculiarities of the Understanding of Controlling in Germany, France and Turkey}

\subsection{Connection Between Culture and Controlling}

Individual behavior and especially its control are highly dependent on national und intercompany culture. Different cultural preferences lead to different reactions to certain forms of planning and control. When providing controlling data, the culturally conditioned subjectivity of the interpretation of information must be taken into account (Hoffjan \& Boucoiran, 2008).

Controlling instruments cannot have the same form in different cultural contexts. Since the beginnings of cultural research, attempts have been made to quantify the term "culture" in order to be able to compare different cultures. Best known cultural research studies come from Hofstede \& Hofstede (2009), Hall \& Hall (1990), Trompenaars \& Hampden-Turner (1997).

\subsection{Operationalization of the Concept of Culture by Hofstede}

In order to describe differences between national cultures and to be able to transfer them into practice, Hofstede's investigations from the 1960s and 1970s are still fundamental. As a first step, Hofstede proposed to operationalize the concept of culture using five cultural dimensions developed by him. The aim of this classification of culture into cultural dimensions is to identify the differences 
between national value systems that influence business activities. His findings are based on a survey of more than 116,000 employees in over 50 countries. Despite all the limitations (e.g. inadmissible generalization, obsolescence), the findings still seem well suited to highlight fundamental differences between cultures.

Hofstede identified the following dimensions (Hofstede \& Hofstede 2009):

Under power distance Hofstede defines social inequality, including the relationship to authority and the emotional distance between employees and superiors (Hofstede 1993, 28 and 38). Power distance shows the degree of willingness to accept or expect an unequal distribution of power in a society or organization. Thus, representatives of cultures with a high power distance are prepared to accept inequality and to subordinate themselves to those in power. The outstanding feature of power distance in companies is that the relationship between superiors and subordinates has a pronounced hierarchical character. On the other hand, the distance between leaders and employees is less great in societies with a small power distance. This means distributed responsibility in business life as well as more independence and autonomy for each individual.

Individualism describes societies in which the tie between individuals is loose: One expects from everyone that he cares for himself and his immediate family. Its counterpart, collectivism, describes societies in which people are integrated from birth into strong, closed "we-groups" that protect them throughout their lives and demand unconditional loyalty. (Hofstede \& Hofstede 2009, 66). In collectivist societies, the preservation of harmony is a virtue as an expression of loyalty; mutual help and support are taken for granted. On the other hand, all members of an individualist society are expected to perform and assert themselves for themselves. The free development of the personality and the formation and expression of one's own opinion are central.

Hofstede uses the dimension masculinity to describe determination as opposed to modesty (femininity). Masculinity characterizes a society in which the roles of the sexes are clearly separated from each other: Men are determined to be hard and materially oriented. Women must be more modest, more sensitive and attach importance to quality of life. Femininity characterizes a society in which the roles of the sexes overlap: Both women and men should be modest and sensitive and attach importance to quality of life (Hofstede \& Hofstede \& Hofstede 2009, 115). Masculine cultures are characterized by the high value placed on status symbols. Overall, they are more performanceoriented, aggressive and competitive. In contrast, in feminine cultures more emphasis is placed on part-time work, childcare facilities, friendships and voluntary work. In masculine cultures, conflicts tend to be resolved through a (fair) struggle, whereas in feminine cultures compromises are usually sought. In addition, gender roles overlap in feminine societies, interpersonal relationships are the focus, empathy is highly valued and goals are achieved through cooperation and willingness to compromise.

Uncertainty avoidance can be defined as the degree to which the members of a culture feel threatened by uncertain or unknown situations (Hofstede \& Hofstede 2009, 158). Cultures with strong uncertainty avoidance are characterized by the need for written and unwritten rules, because the 
general willingness to take risks is low. This is particularly important for cooperation in companies, where there are many internal regulations in addition to the rights and duties of the employer and employee. On the other hand, in cultures with weak uncertainty avoidance, there is a need for renewal and flexible structures. In general, people here are more willing to take risks and are more relaxed about uncertainty situations.

The fifth dimension "short-term versus long-term orientation", which was not considered in Hofstede's original study, describes the extent to which a pragmatic, future-oriented attitude replaces the dogmatic, present-day perspective in a society. Due to the subsequent addition, the evaluation of its expression is based solely on expert estimates, as there are no country-specific studies for the countries requested by Hofstede.

\subsection{Communication-Oriented Differentiation of the Concept of Culture by Hall}

In view of the importance of communication in companies for their success, in addition to Hofstede's findings it seems appropriate to make use of cultural comparisons based on the dimensions of Hall \& Hall (1990). They differentiated national cultures on the basis of three criteria, the first of which is most important:

Type of communication. Due to the so-called context dependence of communication, "high-contextcultures" and "low-context-cultures" are defined.

Relationship to space.

Relationship to time.

In the context of the context dependency of communication, the spatial and climatic conditions, the spatial distance between communicators, but also events of the past, such as previous experiences in similar situations or events immediately preceding communication, are considered. The context is therefore made up of a multitude of individual factors. "Low-context" cultures are fundamentally characterized by direct and explicit communication. The message can thus be received directly by the recipient of the message and does not have to be brought into the context of the environment by the recipient. In contrast, in "high-context" cultures an implicit form of communication prevails. Accordingly, for successful communication in "high-context" cultures it is necessary to have a high degree of understanding for body language and cultural artefacts, for example. Collectivist cultures are usually high-context-bound. There is a distinct information network to family, friends, colleagues and customers, so that no background information is needed for daily business. In individualistic cultures it is necessary to communicate explicitly due to the low importance of relationships; these cultures and therefore rather low-context-bound.

As a further dimension, Hall and Hall identify the relationship to space. In humans, in addition to the skin, there are also other invisible boundaries within the surrounding space as visible boundaries to the outside. Examples of this are the work table, the office or any other delimited territory. The 
significance of territory is particularly pronounced in Germany and the USA. Here the consideration of spaces (such as the kitchen of a cook or the bedroom of a child) as "mine" has a high value and at the same time determines the position of power within a social system or an organization. This can be seen, for example, in the importance attached to the size of an office or to the question of whether an employee has to work in an open-plan office or can have an individual office.

The personal space concerns massively the living together with the fellow human beings. This can be seen, for example, in the demarcation of the intimate area from people and the related attitude to physical contact: In Northern European countries, apart from shaking hands, any kind of touch is not considered opportune, even in long-term relationships. In southern countries, on the other hand, a hug and a kiss on the cheek are an essential signal that there is more than a fleeting relationship. What is important here is that the attitude to physical contact can change over time: For example, it can be observed that in Germany, starting in southern Germany, a hug is gradually becoming established as a greeting, whereas in the Eastern European countries, after the end of socialism, the "brother kiss" is no longer considered opportune and a greater distance is maintained.

As a further characteristic of the relationship to space, Hall identified the space-use systems "star" with pronounced centralism and "grid" with distributed focal points. In the "star" system, there is a centre to which all traffic routes are directed. Distinctive examples are France with Paris and Germany between 1870 and 1945 with Berlin. The "star" type also has a pronounced tendency towards centralism in decision-making. A "grid" system, on the other hand, symbolizes a polycentric system and stands for federalism and distributed competences: Transport networks with several nodes, federal state structure and distributed responsibility in companies. The concepts have different advantages and disadvantages, which can be recognized both within the organization and in relations with the outside world, especially in supranational oriented companies, and which must be taken into account in actions.

According to Hall \& Hall, different national cultures also differ in their relationship to time. He coined the terms monochronic and polychronic dealing with time. In this context, monochrony means focusing one's attention on one thing and dealing with only one thing. In monochronic cultures, time is used linearly, which means that appointments are more important than a random conversation in the kitchen.

\subsection{Cultural Differences between Germany, France and Turkey}

In order to illustrate the importance of intercultural differences, the following overview will take a closer look at Germany, France and Turkey. Following on from the Hofstede cultural dimensions presented in Section 3.2, the following index values for the individual dimensions were determined for the three countries (see Table 1). 
Table 1: Cultural Differences between Germany, France and Turkey

\begin{tabular}{|l|l|l|l|l|l|l|l|}
\hline $\begin{array}{l}\text { Index/ } \\
\text { Culture dimension }\end{array}$ & Rank & \multicolumn{2}{l|}{ Germany } & \multicolumn{2}{l|}{ France } & \multicolumn{2}{l|}{ Turkey } \\
\hline Power distance & $32-33$ of 76 & 35 & Low & 68 & High & 66 & High \\
\hline Individualism & 43 of 76 & 65 & Individualistic & 71 & Individualistic & 37 & Collectively \\
\hline Masculinity & $43-45$ of 76 & 67 & Masculine & 43 & Feminine & 45 & Feminine \\
\hline Uncertainty avoidance & $23-25$ of 76 & 66 & High & 86 & High & 85 & High \\
\hline $\begin{array}{l}\text { Long - vs. short-term } \\
\text { orientation }\end{array}$ & 47 of 93 & 83 & High & 63 & High & 46 & Medium \\
\hline
\end{tabular}

Source: Hofstede (2003)

As neighboring countries and core countries of the European Union, Germany and France have many social similarities that can be explained by the influence of similar influencing factors such as the enlightenment or religion. However, significant differences can also be observed, for example from the different state structure (federalism in Germany. centralism in France), the education system (higher degree of permeability in Germany vs. relatively rigid system of elite education in France; all-day care and school in France vs. dominance of half-day care in Germany, the importance of dual education in Germany) or the gender role understanding (higher degree of emancipation and participation in the economic life of women in France compared to Germany). In addition, the striking difference with regard to the power distance shows that the cooperative management style practiced in Germany in particular with strong involvement of employees in decision-making encounters difficulties in France because hierarchical decision-making structures are established. While bottom-up budgeting processes are common in Germany, for example, top-down budgeting is used in France. The difference in masculinity must also be taken into account, which is reflected, among other things, in the differing importance of objective orientation and personal relationships. With regard to the uncertainty avoidance dimension, there is a distinct tendency in both countries to limit risks as far as possible and, in case of doubt, to take a less risky (but also less high-yielding) alternative. However, this approach to business decisions is even more common in France than in Germany. It must therefore be borne in mind that in France employees at all levels of the company tend to identify low-risk alternatives, delegate decisions "upwards" or safeguard them. In this respect, correlations with the different ways of dealing with hierarchy are also important.

German and Turkish culture also have similarities in many areas, resulting in part from a similar recent history (e.g. late democratization). The results of Hofstede's research also illustrate the major differences between controlling in both countires: Starting from an average value of 50, the values for Germany and Turkey are on different sides of the scale in the dimensions of power distance, individualism and masculinity. With regard to the dimension of power distance, inequality between people is expected and desired in Turkish society. Accordingly, hierarchical structures in organizations are a mirror image of an inequality by nature between the upper and lower strata.

With regard to the dimension of individualism, the German society, which can be described as more individualistic, and the Turkish society, which is regarded as more collectivist, face each other. The effects on business life are manifold, for example in the form of the importance of the family and the 
group of employees, as well as the general importance of relationships that are given priority over tasks. The management of employees is particularly affected by this, as the preservation of harmony and the avoidance of direct disputes must be taken into account as far as possible.

Of decisive importance in dealing with intercultural differences between German and Turkish society, which also have effects on cooperation work in and between companies, is the recognition of the significance of "honour" (namus) and "reputation" (şeref) in Turkish culture (cf. Appl et al. 2016, p. $31 \mathrm{ff}$.). This particularly affects relationships between managers and employees as well as between male and female employees.

A comparison of the three countries also reveals further fundamental differences between Germany and France on the one hand and Turkey on the other. Even if religion is practised to varying degrees and the Turkish constitution explicitly states that there is a separation between state and religion, religion plays a much stronger role in the Turkish population than in Germany or France (Franken 2006, $147 \mathrm{f}$.). This is associated with a relatively low tolerance towards non-Muslims and also Muslims of other faiths.

In addition, cultural diversity within Turkey and the degree of inhomogeneity in Turkish society are significantly greater than in Germany and France. The background to this is the multi-ethical composition of Turkish society (about 20\% of Turks are Kurds), but also the very pronounced differences between the urban, Western-oriented part of the population and the originally rural, traditionalist part of the population, which can now also be found in the large cities.

Even this brief overview shows that the following similarities and differences are or may be relevant in the context of controlling (Table 2):

Table 2: Intercultural Characteristics of Controlling

\begin{tabular}{|c|c|c|c|c|}
\hline & $\begin{array}{l}\text { Influencing cultural } \\
\text { dimension }\end{array}$ & Germany & France & Turkey \\
\hline $\begin{array}{l}\text { Readiness for exchange of } \\
\text { information }\end{array}$ & Collectivism & Individualistic & Individualistic & Collectively \\
\hline Form of information & \begin{tabular}{|l|} 
Power distance, \\
uncertainty avoidance
\end{tabular} & Informal, detailed & Formal, detailed & Formal, detailed \\
\hline $\begin{array}{l}\text { Access to the controlling } \\
\text { relevant information }\end{array}$ & Power distance & Non-hierarchical & $\begin{array}{l}\begin{array}{l}\text { Hierarchical, more } \\
\text { difficult }\end{array} \\
\end{array}$ & $\begin{array}{l}\text { Hierarchical, more } \\
\text { difficult }\end{array}$ \\
\hline $\begin{array}{l}\text { Participation of employees } \\
\text { in the planning process }\end{array}$ & $\begin{array}{l}\text { Collectivism, } \\
\text { distance } \\
\end{array}$ & $\begin{array}{l}\text { Participative } \\
\text { planning }\end{array}$ & Lower share & Lower share \\
\hline $\begin{array}{l}\text { Degree of precision of the } \\
\text { planning systems }\end{array}$ & Uncertainty avoidance & $\begin{array}{l}\text { High degree of } \\
\text { precision }\end{array}$ & $\begin{array}{l}\text { High degree of } \\
\text { precision }\end{array}$ & $\begin{array}{l}\text { High degree of } \\
\text { precision }\end{array}$ \\
\hline $\begin{array}{l}\text { Participation in the control } \\
\text { process }\end{array}$ & Power distance & High & \begin{tabular}{|l|} 
Low \\
\end{tabular} & Low \\
\hline
\end{tabular}

Source: Hoffjan und Boucoiran (2008), Feldbauer-Durstmüller und Keplinger (2012), Feldbauer-

Durstmüller \& Kuttner (2017) 
By this, the following socio-cultural characteristics of controlling in Germany, France and Turkey can be derived (Table 3):

Table 3: Intercultural Characteristics of Controlling

\begin{tabular}{|l|l|l|}
\hline Germany & France & Turkey \\
\hline $\begin{array}{l}\text { tendential flat organizational } \\
\text { structures }\end{array}$ & larger organizational structures & Larger organizational structures \\
\hline $\begin{array}{l}\text { less importance of the hierarchical } \\
\text { principle } \\
\text { strong participation in planning and } \\
\text { control }\end{array}$ & $\begin{array}{l}\text { high importance of the hierarchy } \\
\text { principle } \\
\text { low participation in planning and } \\
\text { control }\end{array}$ & $\begin{array}{l}\text { high importance of the hierarchical } \\
\text { principle } \\
\text { low participation in planning and } \\
\text { control }\end{array}$ \\
\hline $\begin{array}{l}\text { Tendency towards decentralized } \\
\text { structures }\end{array}$ & centralized structures & centralized structures \\
\hline $\begin{array}{l}\text { Direct, explicit and factual } \\
\text { communication silence }\end{array}$ & $\begin{array}{l}\text { indirect, implicit and formal } \\
\text { communication silence }\end{array}$ & $\begin{array}{l}\text { Indirect, implicit and formal } \\
\text { communication silence }\end{array}$ \\
\hline strong performance orientation & $\begin{array}{l}\text { Interpersonal relationships in the } \\
\text { foreground }\end{array}$ & $\begin{array}{l}\text { Interpersonal relationships in the } \\
\text { foreground }\end{array}$ \\
\hline formal rulebook & formal rulebook & formal rulebook \\
\hline Comprehensive and precise reporting & Comprehensive and precise reporting & Comprehensive and precise reporting \\
\hline
\end{tabular}

It can be seen that there are significant socio-cultural differences between the three countries considered. It can therefore be assumed that these differences are also reflected in the design and implementation of controlling systems both in companies in general and in SMEs.

\section{Differences in Controlling Designs}

\subsection{Result of this Preliminary Investigation}

There are several research papers which analyze the usage of controlling in SME. Among several other studies (see e.g. Keuper, Brösel \& Albrecht 2009), the following studies are of special interest:

Hatunoğlu, Akpınar \& Çelik (2013): In the study, the authors have questioned 350 SMEs from the areas Kahramanmaras and Gaziantep about the usage of controlling information. 69.4\% of the companies surveyed believe that the controlling data is important or very important for planning. However, results from the study show that controlling reporting supports the management significantly more in the area of financing activities (67.6\%) and less in the area of production activities (37.1\%).

Mizrahi (2011): In this empirical study, the author has asked 80 SMEs from the industrial district of İzmir (İzmir Atatürk Organize Sanayii Bölgesi) about the effectiveness of their controlling system. From the results of the study it can be deducted that $65 \%$ of the companies surveyed do not use controlling as a source of information for management decisions. The study shows a strong positive relationship between the company size and the intensity of the use of controlling data. 
Tak \& Eroğlu (2010): In this study, the authors have interviewed 470 small and medium sized companies from the district of the Bursa Chamber of Commerce referring to the application of strategy-oriented approaches to corporate governance. The authors found out that the lack of basing strategy decisions was one of the most serious conceptual weaknesses of corporate governance in SMEs. The study showed that only $30 \%$ of companies surveyed had strategic planning.

Doğan (2014): As part of this study, 75 small and medium-sized companies from the Bartın district were surveyed on the use of controlling as an information system for business decisions. The study shows that the controlling data are not used as decision-relevant information in a majority of companies surveyed. The necessary integration of controlling and corporate management is missing.

Ossadnik, Barklage \& Lengerich (2004): The authors surveyed 155 companies, each with less than 500 employees, on functional, instrumental and institutional design of controlling. 64\% of the companies claimed that they had self-controlling filters. This form of institutionalization is present especially in companies with over 200 employees. In 31\% of the companies surveyed, controlling tasks are done part-time. Only in companies with more than 100 employees, the implementation of comprehensive standard controlling instruments can be observed.

Wilken (2007): The study of SMEs in North West Germany shows that controlling now has indeed a firm anchorage in SMEs. However, at the same the range of modern controlling instruments and systems still is comparatively low.

Schindlbeck \& Diringer (2007): This study covering 235 companies shows a strong connection between the assessment of the performance of an existing risk controlling system on the one hand and the company's success on the other: $72 \%$ of companies that assess the performance of their risk controlling as high, have an above-average corporate success. On the contrary, $49 \%$ of companies that assess the performance of their risk controlling as low, only have an average business success.

Diamant Software (2012): What do SMEs understand by "controlling", how does it implement its controlling tasks in practice and what significance and perspective will controlling have in the future? Diamant Software interviewed 320 people from medium-sized companies and organizations as part of this study. For about $80 \%$ of the respondents, accounting data forms the basis for controlling. A total of $76 \%$ of the respondents would like to further develop the company's own controlling system. $67 \%$ expect controlling to gain importance in their company over the next two years.

Over all, recent research shows that the scope of the practical use of controlling procedures in SME is still incomplete. All analyzed studies show the high relevance of a well-designed controlling. Often, the degree of implementation of controlling increases with the growing size of companies. In some areas such as investing, controlling instruments are already quite commonly used (Rautenstrauch \& Müller 2006, 101ff.) However, the studies do not consider the linkage between the implementation of controlling and intercultural differences. 


\section{Conclusion}

SMEs are called the "innovation engine" of an economy and therefore controlling in these companies must be determined as a microeconomic and macroeconomic necessity: In a microeconomic context, it is necessary to keep in mind the limited resources of SMEs and their vulnerability. From a macroeconomic point of view, SMEs are faced - even more than large companies - with the increasing global competition.

Unlike in the past, deficits in SMEs in the fields of controlling can no longer be explained (and excused!) by the lack of controlling tools, which are adapted to SME needs. Therefore, there must be other explanations for the rather low degree of implementation of these tools in SME. There are studies that investigate the expected theoretical effects of cultural differences on the implementation of controlling systems. On the basis of the existing studies, the following results have been identified: In Turkey, accounting, particularly in SMEs, is characterized by the dominance of annual accounts with the aim of tax policy shaping as the primary objective of balance sheet policy. The number of research projects in Germany and France that focus on the implementation of controlling is relatively high compared to Turkey. Particularly in Turkey, despite its great importance, there are no in-depth analyses of SMEs with a focus on controlling.

But there is no empirical evidence for the influence of culture on the controlling system. A research project can provide empirical proof of the influence of cultural differences on the design and implementation of controlling systems in Germany, France and Turkey. This research project in general aims at closing the research gap pointed out in the field of socio-cultural influences on controlling in SME. The project consists of two parts: Part 1 is an Analysis of the status quo of the usage of controlling instruments in German, French and Turkish SMEs. Part 2 consists of a comparative analysis of SMEs in Turkey, France and Germany.

The project has two major objectives: First, the elaboration of socio-cultural idiosyncrasies about the controlling understanding and controlling practices of SMEs in the three countries as well as by business characteristics. Second, the derivation of measures to improve the understanding of the necessity of controlling and the implementation level of controlling.

\section{References}

Alptürk, E. (2008). Küçük ve Orta Büyüklükte İsletmeler (KOBİ) Rehberi. Ankara: Yaklasim Yayincilik.

Appl, C., Koytek, A., \& Schmid, S. (2016). Beruflich in der Türkei: Trainingsprogramm für Manager, Fach - und Führungskräfte. 2. ed., Göttingen: Vandenhoeck \& Ruprecht.

Beck, U. (1992). Risk society: towards a new modernity. London: SAGE Publications.

Benz, C., Buchner, H., \& Burgath, H. J. (1999). Aufbau eines Führungsberichtswesens im internationalisierten, mittelständischen Unternehmen. Controller-Magazin 24(3), 197-204.

Berens, W., Püthe, T., \& Siemes, A. (2005). Ausgestaltung der Controllingsysteme im Mittelstand - Ergebnisse einer Untersuchung. Controlling und Management 49(3), 186-191. 
Chapman, C., \& Ward, S. (2003). Constructively simple estimating: A project management example. Journal of the Operational Research Society 54(10), 1050-1058.

Christopher, M., \& Towill, D. R. (2002). Developing market specific supply chain strategies. International Journal of Logistics Management 13(1), 1-14.

Coleman, L. (2006). Frequency of man-made disasters in the 20th century. Journal of Contingencies and Crisis Management 14(1), 3-11.

Craighead, C. W., Blackhurst, J., Rungtusanatham, M. J., \& Handfield, R. B. (2007): The severity of supply chain disruptions: design characteristics and mitigation capabilities. Decision Sciences 38(1), 131-156.

Dahms, S., \& Siemes, A. (2005). Strategisches Controlling im Mittelstand - Empirische Erkenntnisse und Hilfestellungen $\left(\mathrm{MinD}^{\circledR}\right)$. Controller Magazin 30(3), 227-234.

Dethlefs, L. (1997). Kennzahlencontrolling in kleinen und mittleren Unternehmen (KMU). Frankfurt/Main: Peter Lang Verlag.

Diamant Software (2012): Notwendigkeit oder zu viel Aufwand? Controlling im Mittelstand. Retrieved from https://www.diamant-software.de/studie-controlling-im-mittelstand/ Zugriff

Dintner, R. (1999). Controlling in kleinen und mittleren Unternehmen: Klassifikation, Stand und Entwicklung. Frankfurt/Main: Peter Lang Verlag.

Elsweier, M., \& Nickel, R. (2010). Logistik-Controlling-Studie - Ergebnisse und Handlungsbedarf. Productivity Management 15(2), 50-53.

Emre, Z., \& Budak, A. (2006). Dünya uygulamaları çerçevesinde KOBİ borsalar, TSPAKB Retrieved from https://www.tspb.org.tr/wp-content/uploads/2015/06/AIM_Yayin_ve_Raporlar_Arastirma_Raporlari_ Dun_Uyg_Cer_Kobi_Borsalari.pdf.

Feldbauer-Durstmüller, B., Duller, C., Mayr, S., Neubauer, H., \& Ulrich, P. (2012). Controlling in mittelständischen Familienunternehmen - ein Vergleich von Deutschland und Österreich. Controlling und Management 56(6), 408-413.

Feldbauer-Durstmüller, B. \& Keplinger, K. (2012). Einflüsse kultureller Faktoren auf die Gestaltung der Controllingsysteme in Österreich, den USA und Russland. In: Denk, C. (ed.). Internationale Rechnungslegung und internationales Controlling. Wien: Linde, 161-187.

Feldbauer-Durstmüller, B,; \& Kuttner (2017) Controlling im internationalen Kontext. iKulturelle Einflüsse auf die Informationsversorgung, Planung und Kontrolle. In: Funk, W. \& Rossmanith, J. (eds.). Internationale Rechnungslegung und internationales Controlling. 3. ed., Wiesbaden: Springer, 281-301.

Flacke, K. (2006). Controlling in mittelständischen Unternehmen : Ausgestaltung, Einflussfaktoren der Instrumentennutzung und Einfluss auf die Bankkommunikation. Dissertation University of Münster

Franken, S. (2006). Deutsch-türkische Unternehmenskooperationen, Strategien für erfolgreiche interkulturelle Zusammenarbeit (Alman Türk şirketler kooperasyonu). Saarbrücken : VDM - Verlag Dr. Müller.

Funk, W., Rossmanith, J., \& Eha, C. (2009). IFRS for SMEs - Auswirkungen auf die Gestaltung des Rechnungswesens und des Controllings in KMU. In: Müller, D. (ed.). Controlling für kleine und mittlere Unternehmen, Lohmar: Eul, 153-187.

Giddens, A. (2003). Runaway world: How globalization is reshaping our lives. London: Routledge.

Gleich, R., Hofmann, S., \& Schulze, M. (2006). Controlling. In: Pfohl, H. C. (ed.) Betriebswirtschaftslehre der Mittel - und Kleinbetriebe. Größenspezifische Probleme und Möglichkeiten zu ihrer Lösung. Berlin: Erich Schmidt, 347-376.

Hall, E. T., \& Hall, M. R. (1990): Understanding cultural differences. Yarmouth: Intercultural Press.

Harland, C., Brenchley, R., \& Walker, H. (2003). Risk in supply networks. Journal of Purchasing and Supply Management 9(1), 51-62 
Haşit, G. (2009). Küçük ve Orta Ölçekli Aile İşletmelerinde Kurumsal Yönetim. Ankara: Ekin Yayinevi

Hatunoğlu, Z., Akpınar, Y., \& Çelik, A. (2013). KOBİlerin Yönetiminde Muhasebe Bilgi Sisteminin Önemi: Gaziantep ve Kahramanmaraş Örneği. Üniversitesi İİBF Dergisi, Cilt: 6, Sayı: 2, 307-322, Nigde.

Hegglin, A., \& Kaufmann, H. (2003). Controlling in KMU. Zweckmässige Controlling-Instrumente in Klein und Mittelunternehmen. Der Schweizer Treuhänder 77(5), 359-368.

Hoffjan, A., \& Boucoiran, T. (2008). Kulturelle Aspekte im internationalen Controlling-Beispiel Frankreich. Controlling 20(2), 65-71.

Hofstede, G., \& Hofstede, G . J. (2009). Lokales Denken, globales Handeln. 4. ed. München: DTV.

Hofstede, G. (1993). Interkulturelle Zusammenarbeit. Wiesbaden: Gabler.

Hoogen, M., \& Lingnau, V. (2009). Perspektiven eines kognitionsorientierten Controllings für KMU. In: Müller, D. (ed.). Controlling für kleine und mittlere Unternehmen. München: Oldenbourg, 101-126.

Hult, G. T., Ketchen, M. D. \& Slater, S. F. (2004). Information processing, knowledge development, and strategic supply chain performance. Academy of Management Journal 47(2), 241-253.

Keuper, F., Brösel, G., \& Albrecht, T. (2009). Controlling in KMU - Identifikation spezifischer Handlungsbedarfe auf Basis aktueller Studien. In: Müller, D. (ed.). Controlling für kleine und mittlere Unternehmen, Wiesbaden: Gabler, 56-71.

Kılıç, S. (2011). Küçü ve Orta Ölçekli İşletmelerde İhracat Pazarlaması. Ankara.

Kosmider, A. (1994). Controlling im Mittelstand. 2. ed., Stuttgart: Schäffer-Poeschel.

Kramer, M., \& Valentin, M. (2009). Controlling-Konzeptionen in KMU : Forschungsstand und Auswirkungen auf die Absolventenausbildung unter didaktischen Gesichtspunkten. In: Müller, D. (ed.). Controlling für kleine und mittlere Unternehmen., München: Oldenbourg, 73-100.

Kummert, B. (2005). Controlling in kleinen und mittleren Unternehmen: vom Geschäftsprozessmodell zum Controller-Profil. Wiesbaden: Deutscher Universitätsverlag.

Lachnit, L. (1992). Controllingsysteme für ein PC-gestütztes Erfolgs - und Finanzmanagement, München: Vahlen.

Lachnit, L., \& Müller (2012). Unternehmenscontrolling, 2. ed, Wiesbaden: Springer.

Maaß, F., \& Führmann, B. (2012). Innovationstätigkeit im Mittelstand - Messung und Bewertung. In: Institut für Mittelstandsforschung Bonn (ed.): IfM-Materialien Nr. 212, Bonn.

Mäder, O. B., \& Hirsch, B. (2009). Controlling: Strategischer Erfolgsfaktor für die Internationalisierung von KMU. In: Keuper, F., Schunk, H. A. (ed.). Internationalisierung deutscher Unternehmen. Wiesbaden: Gabler, 171-201.

Miller, K. D. (1998). Economic exposure and integrated risk management. Strategic Management Journal 19(5), 497-514.

Mitroff, I. I., \& Alapaslan, M. C. (2003). Preparing for evil. Harvard Business Review 81(4), 109-115.

Mizrahi, R. (2011). KOBI'lerde Muhasebe Bilgi Sisteminin Etkin Kullanımı Üzerine Bir Araştırma. Organizasyon ve Yönetim Bilimleri Dergisi, Cilt 3, Sayi 2, Mugla

Müftüoğlu, T. (2002). Türkiye’de küçük ve orta ölçekli işletmeler KOBİler: sorunlar, önerile. Ankara: Turhan Kitapevi.

Müller, D. (2009). Controlling für kleine und mittlere Unternehmen. München: Oldenbourg.

Ossadnik, W., Barklage, D., \& Lengerich, E. v. (2004). Controlling im Mittelstand, Ergebnisse einer empirischen Untersuchung. Controlling 16(11), 621-630.

Peemüller, V. (1992). Controlling, 2. ed., Herne, Berlin: Verlag Neue Wirtschafts-Briefe.

Rahman, M., Kumaraswamy, M. (2002). Joint risk management through transactionally efficient relational contracting. Construction Management \& Economics 20(1), 45-54. 
Rammer, C., Aschhoff, B., Crass, D., Doherr, T., Hud, M., Köhler, C., Peters, B., Schubert, T., Schwiebacher, F. \& ZEW (2014). Innovationsverhalten der deutschen Wirtschaft: Indikatorenbericht zur Innovationserhebung 2013. Mannheim. Retrieved from http://ftp.zew.de/pub/zew-docs/mip/13/mip_2013.pdf.

Rautenstrauch, T., \& Müller, C. (2005). Verständnis und Organisation des Controlling in kleinen und mittleren Unternehmen. Zeitschrift für Planung und Unternehmenssteuerung 16(2), 189-209.

Rautenstrauch, T, \& Müller, C. (2006). Investitionscontrolling in kleinen und mittleren Unternehmen. Controlling \& Management 50(2), 100-105.

Rehn, J. (1998). Integrative Planungs - und Kontrollsystem für mittlere Unternehmungen. Konzeption, Gestaltung und empirisches Schlaglicht. München: Hampp Verlag.

Sarısoy, İ., \& Sarısoy, S. (2008). Küçük ve orta ölçekli işletmelere yönelik vergi teşvik politikası. DergiPark Akademik, cilt 25, Sayi 2, , Istanbul:Ticaret Odası Yayınları

Schade, S. (2007). Kennzahlengestütztes Controlling für mittelständische Unternehmenskooperationen. Frankfurt/ Main: Peter Lang Verlag,

Schindlbeck, K., \& Diringer, F. (2007). Controlling im Mittelstand: Repräsentative Studie über das Controlling in Mittelständischen Unternehmen in Deutschland, Fachhochschule Deggendorf. Retrieved from: http:// www.commit-institut.de/pdf/haufeakademie.pdf.

Schöning, S., \& Ersen Cörmert, C. (2018). Risk Controlling in SME - a German-Turkish Perspective, in: Bakırc1, F., Heupel, T., Kocagöz, O., Özen, Ü. (eds.). German-Turkish Perspectives on IT and Innovation Management, Wiesbaden: Springer, 429-446.

Schulze, F. (2010). KMU im Wandel. Mehrwert im Mittelständischen Unternehmen durch Implementierung eines Beschaffungscontrollings. Hamburg: Diplomica Verlag.

Tak, B., Eroğlu, U. (2010). Küçük ve Orta Ölçekli İşletmelerin Stratejik Bir Yaklaşım ile Yönetilip - Yönetilmediğini Tespit Etmeye Yönelik Bir Saha Çalışması. 4. Aile İşletmeleri Kongresi, Kongre Kitabı, İstanbul: Kültür Üniversitesi Yayınları.

Trompenaars, F., \& Hampden-Turner, C. (1997). Riding the waves of culture. London: Brealey.

Weber, J. (2002). Einführung in das Controlling. 9. ed., Stuttgart: Schäffer-Poeschel.

Wilken, C. (2007). Controlling in KMU: Eine empirische Untersuchung im Nordwesten Deutschlands. Fachhochschule Oldenburg/Ostfriesland/Wilhelmshaven, Fachbereich Wirtschaft - Emden. Retrieved from: http://www.hs-emden-leer.de/web/forschung/docs/Forschungsbericht_060.820.07121912.pdf.

Wolf, T., Kuttner, M. \& Feldbauer-Durstmüller, B. (2017). Anforderungen an Controller in KMU. In: Müller, D. (ed.). Controlling für kleine und mittlere Unternehmen. 2. ed., Berlin: De Gruyter Oldenbourg, 2-33 DOI: 10.1515/978.311.0517163-001.

Zimmermann, C. (2001). Controlling in international tätigen mittelständischen Unternehmen. Wiesbaden: Gabler. DOI: 10.1007/978-3-322-89653-7.

Zünd, A. (1979). Zum Begriff des Controlling, in: Goetzke, W., \& Sieben, G. (ed.). Controlling - Integration von Planung und Kontrolle, Köln: GEBERA, 15-26. 